\title{
Windows of equity? Media review of Czech gender hegemony during the 2018 Winter Olympic Games
}

\author{
William Crossan ${ }^{1}$, Lucie Hřebenářová ${ }^{1}$, and Taryn Price ${ }^{2}$ \\ ${ }^{1}$ Faculty of Physical Education and Sport, Charles University, Prague, Czech Republic; and ${ }^{2}$ School of Kinesiology, Applied Health and \\ Recreation, Oklahoma State University, Stillwater, United States
}

\section{Abstract}

Background: Sport media coverage of women's participation has long been viewed as perpetuating hegemonic masculinity. Yet several authors have found recent coverage of mega, multi-sport events, such as the Summer Olympic Games, to be more equitable towards women, particularly when examined proportionally to participation. The Czech Republic for various reasons has traditionally been resistant to feminist ideology, marking its unique positioning in providing an equitable presentation of women's participation. Objective: To examine the influence of hegemonic masculinity in an Eastern European culture, portrayed through Czech online media coverage of the 2018 Winter Olympic Games. Methods: Online media coverage of the 2018 Winter Olympic Games was examined for gendered differences of Czech athletes. Analysis of number of articles, length of articles, type of sport, and whether the article was about domestic or foreign athletes, was evaluated over 17 days of media coverage on two dominant Czech sport media websites. Results were compared in relation to gender, participation rates and medal success. Results: A total of 860 articles were reviewed,

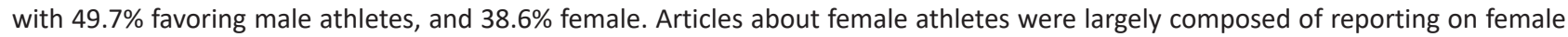
medal winners (medal winning: media coverage correlation .845, $p<.001$ ), while those on male athletes were predominantly from the cultural dominant sport of men's ice hockey (25.1\%). Conclusions: The findings suggest that success is more important than perpetuations of hegemonic masculinity when men and women are competing in mega, multi-sport events. Implications of these findings are also provided in terms of type of media coverage and influences of equity in media coverage for the 2018 Winter Olympic Games.

Keywords: Czech Republic, media, national identity, online, sport

\section{Introduction}

Resulting from the equal employment of genders under communism (True, 1999), and the apparent high value of women in society during the foundational inter-war First Republic (Šiklová, 1997), the Czech Republic has traditionally been portrayed as resistant to feminist ideology (Oates-Indruchová, 2016). Hegemonic masculinity has been identified in many facets of Czech society, despite this apparent cultural resistance to an ideology (True, 2003; Věšínová-Kalivodová, 2005), including Czech sport. Sport culture is considered to be a social institution that influences and reinforces social structures. In turn, aligned with traditional assumptions of sport's masculine pervasiveness, Czech sport participation and media coverage has been observed to reinforce male superiority (Stříteský, 2015).

Participants and consumers of sport culture often use various media outlets to acquire up to date results, background information, and the latest news items on their favorite teams and individual participants. However, the sport coverage these consumers and participants receive are laden with values that reinforce traditional notions of gender and national identity. Identified as one of the most internationally influenced sporting ventures, the Olympic Games, media coverage is assumed to be most representative of a nation's pride and values (Billings \& Angelini, 2007; Billings et al., 2013; Cho, 2009). As such, scholars have consistently sought to examine the ways various media outlets provide coverage of men and women's Olympic participation.

Men's sport coverage often highlights men being bigger, faster and stronger, than their female counterparts. This tradition has only been disrupted when sport is evaluated artistically, or during women's success in mega multi-sex events, such as the Olympic Games (Billings et al., 2008; Coche \& Tuggle, 2016). Emphasis on women's artistic movements in sport are highlighted, even when performing the same movements men perform during competition (i.e., freestyle skiing; Greer \& Jones, 2013). Gender coverage between the sexes is only stifled when women outperform men in competition (Billings \& Angelini, 2007; Eagleman et al., 2014). Outside of the external acknowledgements of success, traditional gender differences tend to be emphasized, reinforced, and socialized through sport media coverage. The inequitable presentation of women's

\footnotetext{
$\triangle$ Corresponding author: William Crossan, e-mail william.crossan@gmail.com, ORCID ${ }^{\circledR}$ record https://orcid.org/0000-0003-3335-430X

Article history: Received September 21 2020, Accepted February 2 2021, Published April 132021

Copyright: (c) 2021 The Author(s). Published by Palacký University Olomouc. This is an open access article distributed under the terms of the Creative Commons Attribution License (https://creativecommons.org/licenses/by/4.0/), which permits unrestricted use, distribution, and reproduction in any medium, provided the original author and source are credited. This license does not cover any third-party material that may appear with permission in the article.
} 
visibility in sport prompts criticism of sport media's maintenance of sport's masculine social construction (Cooky et al., 2015; Jakubowska \& Ličen, 2019; Kidd, 2013).

In the current paper, sport media coverage is analyzed in the Czech Republic in order to identify patterns of hegemonic masculinity. The current assessment is aligned with Delorme and Pressland's (2016) call for studies from various cultural contexts. The most followed sports in the Czech Republic are football and ice hockey (Č́slavová et al., 2007). In general, Pokorná (2016) found that 83\% of Czech print sport media covers men. On a daily average, online sport media websites will each produce 14-20 articles about both football and ice hockey. These articles will include coverage of the home league, as well as international leagues, such as the football's UEFA Champion's League or ice hockey's NHL. Yet articles about women's participation in these two dominant Czech sports appear only once in two weeks on these same sport media websites. This imbalanced trend in media coverage, in favor of men, is troubling considering that the women's teams in each of these sports consistently outperform men in the UEFA Women's Champions League and IIHF European Women's Champions Cup, respectively.

Sekot (2006) examined the Czech print media coverage of the 2004 Summer Olympic Games in Athens. He examined 817 total articles from three print newspapers, finding $52.4 \%$ of articles covered male athletes, $34.8 \%$ female athletes, and $12.9 \%$ covered both genders. These numbers corresponded to the $57 \%$ male to $43 \%$ female composition of the Czech team in Athens. Similarly, Slepičková (2010), found that even when taking into account participation proportionality, Czech newspaper coverage during the 2004 Olympic Games under-represented women and over-represented men by $5-7 \%$. Slepičkovás findings are similar to the multiple other studies illustrating the disparity between media coverage of men and women originating in the West (Cooky et al., 2015; Davis \& Tuggle, 2012; George et al., 2001).

Several authors have examined men and women's media coverage fairness in Eastern European countries, such as Slovenia (Brown et al., 2017; Ličen \& Billings, 2013a, 2013b), and Poland (Jakubowska \& Ličen, 2019). Building on these findings, the current study examines the influence of hegemonic masculinity in an Eastern European culture, portrayed through Czech online media coverage of the 2018 Winter Olympic Games. A critical feminist framework is employed, asserting that media representation does not just reflect reality, but also structures and shapes gender perceptions in sport.

\section{Hegemonic masculinity}

Sport has traditionally fostered hegemonic masculinity, an ideological stance that privileges traditionally masculine traits, such as aggression and physical violence; marginalizing the characteristics and qualities most associated with women participants (Kidd, 2013). Hegemonic masculinity is the privileging of masculinity, qualities most associated with men, over femininity, most associated with women. Men are acknowledged as superior athletes and competitors, while women's contributions are often overlooked (Kidd, 2013).

The concept of hegemony originated from Gramsci (1971) to describe the ideological forces that allow for a hierarchical organization of individual interactions and social practices. Power is established and maintained in a nonviolent, nonphysical manner, such that the ideas of a dominant class are exerted over subordinate groups by means of persuasion, consensus, and manipulation (Connell, 2005). Connell has written extensively about how gender serves as a social construct that is mediated by hegemonic ideals (Connell, 1990, 2005). Examination of gender's hierarchical social construction has identified sport leadership positions, opportunities for upward mobility, sport media coverage, among other contributors, as perpetuators of sport's hegemonic masculine construction.

Sage (1998) suggested that sport serves as one of most hegemonic institutions in society, due to its masculine structure. Sport has traditionally been a male preserve enabling boys to mature into men (Kidd, 2013). The socialization process reinforces gendered roles that laud the benefits of athletic participation for men, but not women. Men are pushed to dominant aggressive sports such as ice hockey, while women are discouraged on the grounds that such sports are not feminine. Women are praised when they pursue 'socially appropriate' sports: artistic sports such as figure skating, which put their natural beauty on display; or individual non-contact sports such as cross-country skiing (Adams et al., 2005; Billings et al., 2008). The labeling of men and women's athletic contributions are magnified by sport media coverage. Sport media coverage serves as a prominent tool that can perpetuate the perception and understanding of a subordinate class through the presentation of ideals and values of the dominant class to maintain hegemonic masculinity.

The perpetuation of hegemonic masculinity has inextricably been tied to cultural values. Cultural values related to gender dominance are more often in alignment with the social construction of sport - privileging the participation and success of men. To maintain the status quo, in sport, scholars have recognized that the presentation of men and women serves as a microcosm of societal views and cultural values. In turn, the portrayal and presentation of men and women in sport have the ability to shape and reify societal beliefs of men and women (Fink, 2015; McCombs, 2005). This belief calls attention to the influence of men and women's sport media coverage on the value of men and women in society.

\section{Gender and sport media coverage}

Multi-sport mega events and online sport media coverage appear to be slowly disrupting hegemonic masculinity. Increasingly researchers are finding the media coverage of women's sports to be more equitable; when the analytical gaze is shifted away from the most visible, dominant sports in a culture (Kian \& Clavio, 2011; Vincent, 2004). As such, the Olympic Games provides the best opportunity to examine gender differences in media coverage due to the various competitive matches occurring, simultaneously. During 
the Olympic Games, the best male and female athletes are able to compete and represent their country, heightening nationalistic pride in media coverage (Billings \& Angelini, 2007; Vincent et al., 2002). Much research has focused on the Olympic Games where relatively equal numbers of men and women are competing in the same sporting event at the same time. More recent research indicates that there is increasingly more fair coverage of women in these contexts.

Scholarship surrounding various types of media coverage has provided mixed results regarding the influence of the type of medium (i.e. print) used to cover men's and women's participation has on viewership and commentary. Traditional media has consisted of print and newspapers and has predominantly focused on men (Burch et al., 2012), with few exceptions (Hardin et al., 2002). New media (i.e. online) has been observed to provide more opportunities for well-rounded coverage of men and women athletes and athletic events (Burch et al., 2012; Kian \& Clavio, 2011; Kian et al., 2009). In result, online coverage of various national and international events has been identified as providing more equitable coverage of men and women sport competitions (Coche \& Tuggle, 2016; Eagleman et al., 2014; Kian et al., 2009).

Scholars have looked to the new media coverage of the Olympic Games to better understand the widespread presence of bias regarding gendered media coverage. Burch et al. (2012) identified increased, equitable amount of coverage between men and women. Their results still criticize the quality of coverage men and women receive. Burch et al.'s study identified no statistical significance between men and women's Olympic coverage, when considering participation rates; denoting a "positive step in regards to coverage of female athletes” (p. 12). Delorme (2014) went further, re-examining 18 studies of the Summer Olympic Games taking into account participation rates and number of female events. When combining all factors, he found that women are only underrepresented in $22.24 \%$ of cases, which was significantly lower than the original studies indicated. Coche and Tuggle (2016) conducted a gender analysis of NBC's coverage of the 2012 London Summer Games and found that there was more coverage of women's events than men's; even though the coverage was based on "socially acceptable" sports. In alignment with hegemonic masculine ideals, the characteristics of individuals are relegated to qualities along the masculine-feminine continuum.

\section{National identity and sport media coverage}

Similarly, scholars have consistently found that Olympic media coverage reproduces narratives which reinforce national values and feelings of national pride (Milford, 2012; Min \& Zhen, 2010). Media coverage within a country during international sport events contributes to national identity by creating national heritage around victory or defeat as they unfold, or by recalling past performances (Billings \& Angelini, 2007; Maguire \& Poulton, 1999). We are defining national identity here as, "a conception of common cultural heritage, patriotism as a pride in this heritage, and nationalism as the promotion of this national identity as being inherently superior to all other nation states" (Billings et al., 2013, p. 914). Similar to hegemonic masculinity, national identity is reinforced in media coverage by creating perceptions of different identity groups, and often accessing value to each identity group. As such, there is a necessity to examine media coverage in reference to the value placed on these identity groups, particularly in terms of gender and national identity. Delorme stated, "the inherent cultural and structural specificities of each country (e.g., predominance of male hegemony) are able to significantly influence the media coverage of sports according to athletes' sex" (Delorme, 2014, p. 143).

When gender and sport media coverage have been studied in other Eastern European countries, themes of hegemonic masculinity and national identity appear stronger than in western countries. Brown et al. (2017) found that portrayal of national identity, while differentiated from western nations such as the United States, was equally important in a new, small nation, such as Slovenia. A study of Slovenian television coverage of the 2008 Olympic Games stated that notions of nationality and gender using content analysis "would be deemed inappropriate in many societies," (Ličen \& Billings, 2013b, p. 379). The Slovenians won two medals, but national identity was enforced as, "Sports announcers behave as (although mild) patriotic supporters, rather than reporters," (p. 392), and coverage of individuals and teams expected to perform well was higher than other Slovenian athletes competing (Ličen \& Billings, 2013b). Similarly, Jakubowska and Ličen's (2019) study of newspaper coverage of the Polish teams participating in the European Basketball Championships found 3.5 times more coverage of the men's team than the women's team, and significantly longer articles about the men's championships than women's. Importantly, the author's state, "The divide identified in this study of Polish basketball coverage represents a significant departure from the communist-era promotion of gender equality and women's empowerment in all areas of society including sport" (Jakubowska \& Ličen, 2019, pp. 316-317). These findings are significant for the cultural parallels between the Czech Republic and these two other Eastern European, post-communist nations.

The current study seeks to quantitatively assess Czech 2018 Winter Olympics online media coverage of men and women participants. Burch et al.'s (2012) analysis of the 2010 Winter Olympic Games identified 'gender appropriate', 'socially acceptable' sport coverage between men and women. The amount of coverage devoted to men and women, type of sport, length of articles, and participation rates will be analyzed to identify the presence of gendered discriminatory media coverage in Czech sport media.

\section{Research questions}

What gender inequities between men and women's online sport media coverage are observed during the 2018 Winter Olympics for Czech athletes?

What influence does participation and performance have on the number of articles devoted to men and women?

What impact does article length provide when comparing men and women's participation and performance? 


\section{Methods}

\section{Overview}

For the purpose of this research, a quantitative content analysis was conducted focusing on two dominant Czech online sports websites. Quantitative descriptors examined include: number of articles, length of articles, type of sport and whether the article was about domestic or foreign male and female athletes.

\section{Data set}

The choice of data set was modeled on previous online gender media analysis (Burch et al., 2012; Eagleman et al., 2014). The digital media analysis tool rating.gemius.com was used to select the media outlets reviewed. The tool analyzes website traffic, monitors page views and time spent per page. The first monitored file derived from sport media outlet sport.cz after specifying the Winter Olympics 2018 period, and identifying the outlets highest rating regarding searches for sports pages having the highest values of all descriptors. The results for the portal sport.cz were in all monitored categories at least twice as high as the results of other servers.

The second and third place results had similar values, namely the media outlets sport.idnes.cz and isport.blesk. $\underline{\mathrm{cz}}$. Thus, the second portal sport.idnes.cz was chosen for review.

\section{Data collection}

Data was collected on articles for the period February 8-25, 2018. Data collection began one day after the official opening ceremonies and extended to include dates beyond the official competition schedules, similar to previous studies (Kian \& Clavio, 2011; Sekot, 2006). For ease in comparison with other studies, the current research does not include articles covering the opening and closing ceremonies, or articles which did not relate to participants' sporting activities, such as general reviews or evaluations of the Pyeongchang Games (Davis \& Tuggle, 2012).

\section{Quantitative analysis}

Number of articles was the primary quantitative descriptor. Similar to comparison studies when articles referred to both males and females in the same article, the article was categorized as both, rather than male or female (Burch et al., 2012; Davis \& Tuggle, 2012; Eagleman et al., 2014; George et al., 2001; Kian \& Clavio, 2011; Vincent, 2004). Proportionality is based on this descriptor. The data are compared based on participation proportion, called for by Malec (1994).

Article length is compared based on George et al. (2001). However, these authors calculated article length based on the number of standardized newspaper lines. Measuring online mediums, the word-per-article method was used in this study, with delineations into three categories: articles up to 200 words, articles with 201-400 words, and articles over 400 words. Article length does not include article titles or photo captions.

Articles were categorized and compared per type of sport (Burch et al., 2012; Davis \& Tuggle, 2012; Eagleman et al., 2014), with categories based on officially recognized sports of the 2018 Winter Olympics, such as biathlon, skating, curling, ice hockey, skiing. Bobsled and luge were merged into one category due to the small Czech presence in the data sample.

Individual articles were also analyzed based on their comparison of domestic or foreign athletes, as observed by Sekot (2006). Articles were classified as foreign if they predominately reported on men or women from countries other than the Czech Republic.

\section{Data analysis}

Data was recorded manually and analyzed using Microsoft Excel (Version 2016; Microsoft, Redmond, WA, USA). All statistics (Spearman correlations, $\chi^{2}$, and $d f$ ) were calculated in IBM SPSS Statistics (Version 26; IBM, Armonk, NY, USA). All articles relating to the Olympic Games on the above identified media websites from February 8 to $25^{\text {th }}$, 2018 were read by two independent researchers. A total of 860 articles were reviewed.

Data on individual descriptors was compared between genders, between sports, and between both sports media servers. Proportionality in relation to participation was given high consideration.

\section{Results}

A total of 860 articles from the 2018 Winter Olympic Games from the media servers sport.cz and sport.idnes.cz were analyzed. The participation and success rates of the Czech Olympic team during the 2018 Winter Olympics are reported in Table 1. Overall participation was 58.6\% male and $41.4 \%$ female; the Czech team ratio was lower at $72.3 \%$ and $27.7 \%$, respectively. It should be noted that in terms of participation, $26.6 \%$ of the Czech team was composed of the men's ice hockey team. In terms of Czech success, six of the seven medals won were won by women. The only two gold medals came from Ester Ledecka, who took a surprise win in alpine skiing's super G; as well as snowboarding parallel giant slalom where Ledecka had been ranked at the top of the world for two consecutive years. Participation and performance numbers help to establish a standard of comparison for quantity of media coverage devoted to sport, gender and success.

As Table 2 and Figure 1 illustrate, media coverage largely reflected athlete participation by sport. Results of the Spearman correlation indicated that there was a positive association between sport participation and media coverage $\left(r_{s}=.659, p=.03\right)$. This significance of this correlation increases when we separate genders in regards to male and female participation and media coverage (male: $r_{\mathrm{s}}=.608$, $p=.04$; female: $\left.r_{s}=.876, p<.001\right)$. When coverage exceeded participation (biathlon, skiing, snowboarding and speed skating), it is primarily explained by the Czech team winning medals in those sports. Spearman correlations of medal winning and media coverage were not significant for men $\left(r_{s}=.401, p=.22\right)$, but were highly significant for women $\left(r_{s}=.845, p<.001\right)$. Coverage was greater than representation in the sport of Curling, as Czechs had no 
Table 1 Participation and success

\begin{tabular}{lrcc}
\hline & Total & Men & Women \\
\hline All Olympians & 2908 & $1704(58.6 \%)$ & $1204(41.4 \%)$ \\
Czech team & 93 & $68(72.3 \%)$ & $25(27.7 \%)$ \\
Czech medals & 7 & $1(14.4 \%)$ & $6(85.7 \%)$ \\
Biathlon & 9 & $5(55.6 \%) 1 \mathrm{~S}$ & $4(44.4 \%) 1 \mathrm{~B}$ \\
Bobsleigh and luge & 15 & $14(93.3 \%)$ & $1(6.7 \%)$ \\
Cross-country skiing & 10 & $5(50.0 \%)$ & $5(50.0 \%)$ \\
Curling & 0 & $0(0.0 \%)$ & $0(0.0 \%)$ \\
Figure skating & 5 & $3(60.0 \%)$ & $2(40.0 \%)$ \\
Ice hockey & 25 & $25(100 \%)$ & $0(0.0 \%)$ \\
Nordic combined & 4 & $4(100 \%)$ & $0(0.0 \%)$ \\
Skiing & 10 & $5(50.0 \%)$ & $5^{\mathrm{a}}(50.0 \%) 1 \mathrm{G}$ \\
Ski jumping & 5 & $5(100 \%)$ & $0(0.0 \%)$ \\
Snowboarding & 7 & $2(28.6 \%)$ & $5^{\mathrm{a}}(71.4 \%) 1 \mathrm{G}, 1 \mathrm{~B}$ \\
Speed skating & 4 & $0(0.0 \%)$ & $4(100 \%) 1 \mathrm{~S}, 1 \mathrm{~B}$ \\
\hline
\end{tabular}

Note. Speed skating includes short- and long-track speed skating. Skiing includes alpine and acrobatic. G = gold medal; $\mathrm{S}=$ silver medal; $\mathrm{B}=$ bronze medal. a Ester Ledecká competed in both skiing and snowboarding, thus is counted twice in sports.

Table 2 Media coverage by sport

\begin{tabular}{|c|c|c|c|c|}
\hline Sport & Total & Men & Women & Both \\
\hline Biathlon & 107 (12.4\%) & 45 (42.1\%) & $48(44.9 \%)$ & $14(13.1 \%)$ \\
\hline Bobsleigh and luge & $45(5.2 \%)$ & $25(55.6 \%)$ & $18(40.0 \%)$ & $2(4.4 \%)$ \\
\hline Cross-country skiing & $49(5.7 \%)$ & $23(46.9 \%)$ & $20(40.8 \%)$ & $6(12.2 \%)$ \\
\hline Curling & $21(2.4 \%)$ & $12(57.1 \%)$ & $4(19.0 \%)$ & $5(23.8 \%)$ \\
\hline Figure skating & $40(4.7 \%)$ & $9(22.5 \%)$ & $8(20.0 \%)$ & $23(57.5 \%)$ \\
\hline Ice hockey & $216(25.1 \%)$ & 203 (94.0\%) & $9(4.2 \%)$ & $4(1.9 \%)$ \\
\hline Nordic combined & $8(0.9 \%)$ & $8(100 \%)$ & $0(0.0 \%)$ & $0(0.0 \%)$ \\
\hline Skiing & $136(15.8 \%)$ & $42(30.9 \%)$ & $89(65.4 \%)$ & $5(3.7 \%)$ \\
\hline Ski jumping & $19(2.2 \%)$ & $16(84.2 \%)$ & $3(15.8 \%)$ & $0(0.0 \%)$ \\
\hline Snowboarding & 99 (11.5\%) & $25(25.3 \%)$ & $71(71.7 \%)$ & $3(3.0 \%)$ \\
\hline Speed skating & 89 (10.4\%) & 17 (19.1\%) & $65(73.0 \%)$ & $7(7.9 \%)$ \\
\hline Multiple sports & $31(3.6 \%)$ & $0(0.0 \%)$ & $0(0.0 \%)$ & 31 (100.0\%) \\
\hline
\end{tabular}

Note. Total percentages are from 860 total articles. Percentages by gender are of total articles about the individual sport.

Figure 1 Participants to media coverage

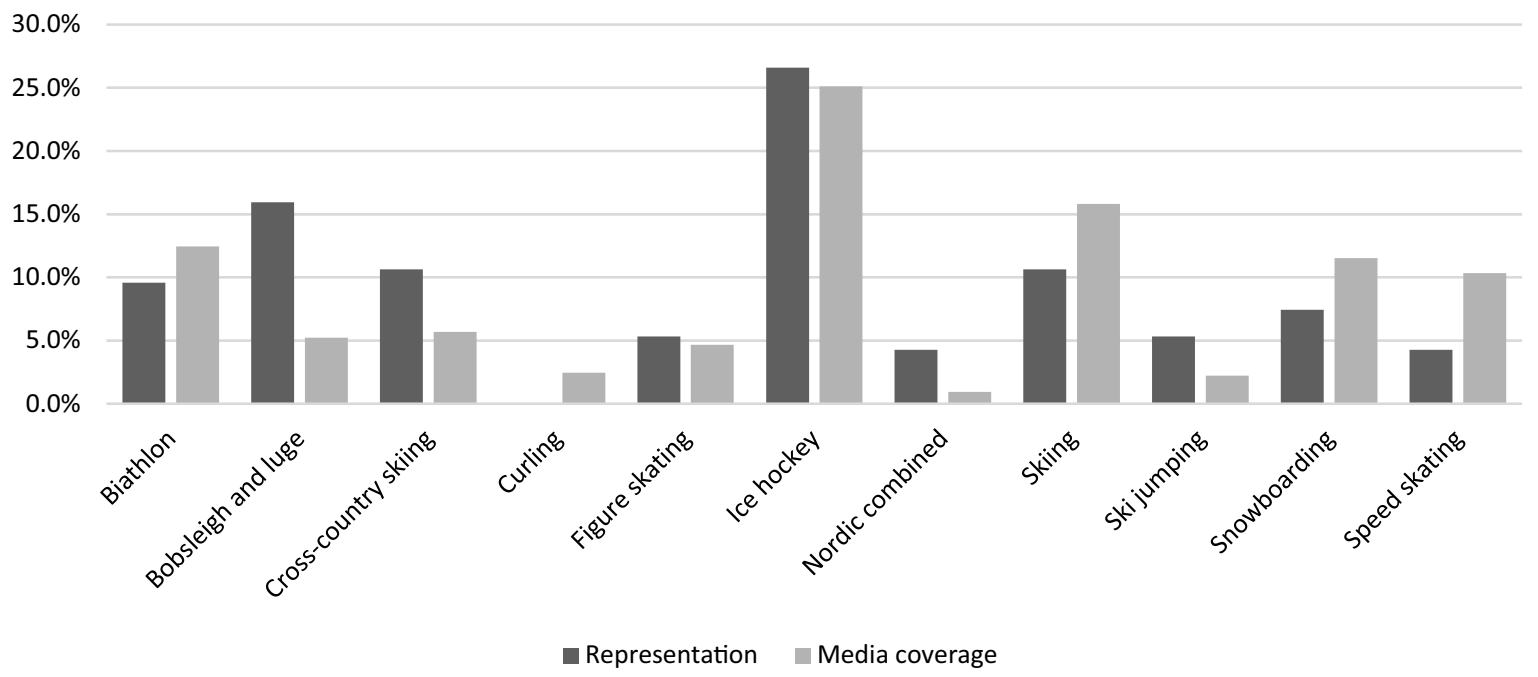

Note. Percentages represent percent of total media coverage to the individual sport and percent of Czech representation by sport. 
participants, and all articles written were about foreign athletes. When we compare media coverage by sport to participation (Tables 1 and 2, Figure 2), a similar pattern displaying coverage exceeds participation when there were no Czech participants (i.e., curling for men and women, ice hockey for women, ski jumping for women, and speed skating for men); and when Czech medals were won (biathlon for women, skiing for women, and snowboarding for women). Interestingly, men's coverage of biathlon did not exceed participation even though a silver medal was obtained there.

Table 3 shows, of the 860 total articles, $49.7 \%$ covered men, $38.6 \%$ women, and $11.7 \%$ reported on both sexes $\left(\chi^{2}(2)=10.45, p=.005\right)$. Results can be compared between media servers, with sport.cz offering almost equal coverage between the genders, while sport.idnes.cz dedicated significantly more articles to men, than women. When reporting on foreign athletes, coverage significantly favored men, while coverage of Czech athletes was almost equal.

The number of articles were analyzed in more detail, on the basis of proportional participation (Malec, 1994). For the purposes of this research, proportional participation is the ratio of men $(70.5 \%)$ and women $(29.5 \%)$ participating as members of the Czech team (Burch et al., 2012). Czech women appear to have received significantly more coverage than their proportional participation would predict, while foreign athletes' coverage was much closer to their proportional gendered participation. If results are compared to proportional medal success (Table 1), with $85.7 \%$ of medals won by Czech women participants, then women should have received significantly more coverage. When reporting on medals won, or athletes from whom medals are expected, sport editors generally report on the performance itself, with interviews of athletes and coaches, both before and after the performance.

Length of the articles was examined. The 17 video reports were not included in this analysis, so the data set was reduced to 843 . It was hypothesized that articles covering men would be longer than articles about women. Overall, as displayed in Table 4, articles most commonly ranged 201-400 words, and the difference in article length between men and women was insignificant $\left(\chi^{2}(4)=4.33\right.$, $p=.363)$.

\section{Figure 2 Gendered participants to media coverage}

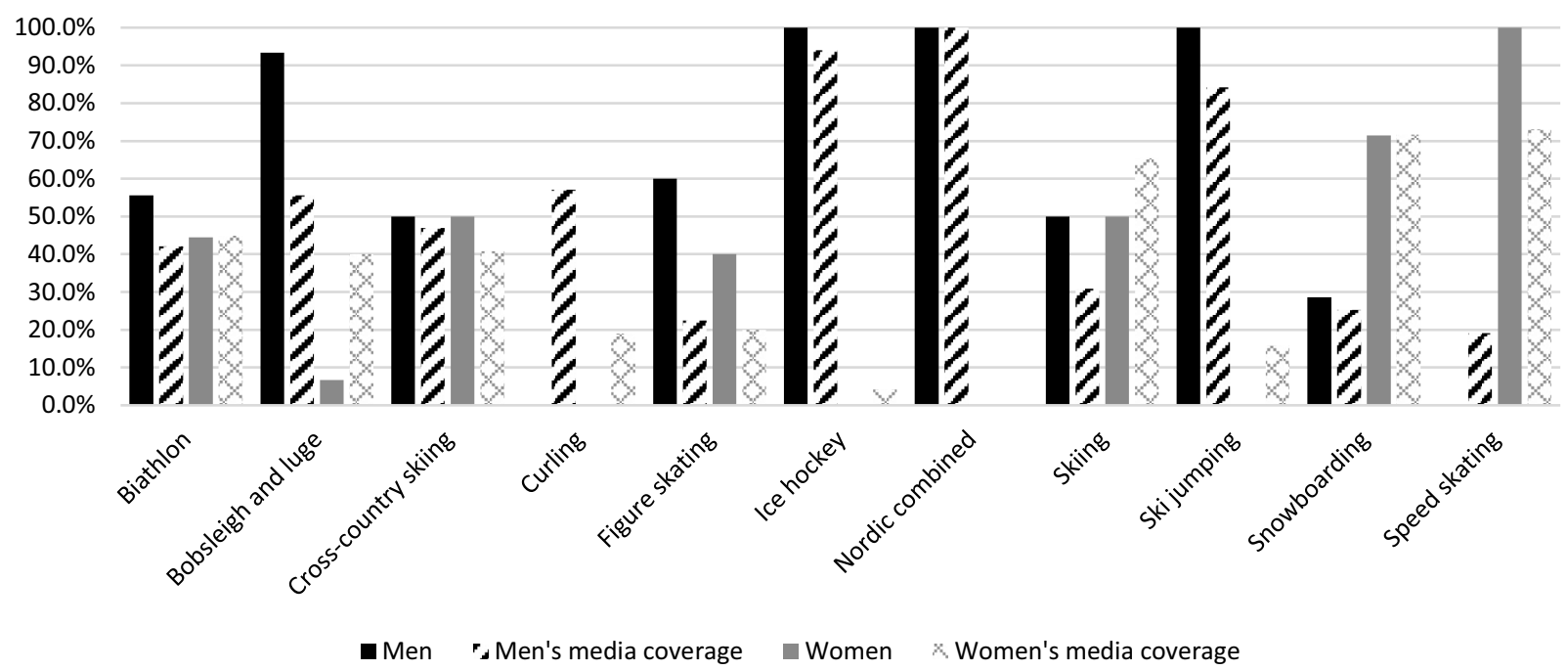

Note. Percentages represent media coverage by sport and Czech representation by sport.

Table 3 Media coverage by gender, server and nationality

\begin{tabular}{|c|c|c|c|c|c|}
\hline & Total & sport.cz & sport.idnes.cz & Foreign athletes & Czech athletes \\
\hline Men & 427 (49.7\%) & 171 (44.1\%) & $256(54.1 \%)$ & $184(57.5 \%)$ & $243(45.0 \%)$ \\
\hline Women & 332 (38.6\%) & $172(44.3 \%)$ & $160(33.9 \%)$ & 94 (29.4\%) & 238 (44.1\%) \\
\hline Both & $101(11.7 \%)$ & 45 (11.6\%) & 56 (11.9\%) & 42 (13.1\%) & 59 (10.9\%) \\
\hline Total & 860 & 388 & 472 & 320 (37.2\%) & 540 (62.8\%) \\
\hline
\end{tabular}

Table 4 Article length by gender

\begin{tabular}{|c|c|c|c|c|}
\hline & Total & Men & Women & Both \\
\hline$\leq 200$ words & 131 (15.5\%) & $56(13.4 \%)$ & $58(17.9 \%)$ & $17(17 \%)$ \\
\hline $201-400$ words & 409 (48.5\%) & 216 (51.6\%) & $147(45.4 \%)$ & $46(46 \%)$ \\
\hline$>400$ words & $303(36.0 \%)$ & $147(35 \%)$ & $119(36.7 \%)$ & $37(37 \%)$ \\
\hline Total & 843 & 419 & 324 & 100 \\
\hline
\end{tabular}

Note. Percentages are by column. 


\section{Discussion}

The number of articles based on gender was primarily investigated, and this study found uneven distribution in favor of men, namely $49.7 \%$ for male athletes and $38.6 \%$ for female athletes. These results parallel those found in television research of the 2008 Summer Olympics (Davis \& Tuggle, 2012), the US Open in 2007 (Kian \& Clavio, 2011), as well as the Wimbledon tennis tournaments of 2000 (Vincent, 2004). Assessing new media coverage in the 2012 Summer Olympics, men consistently had a higher overall percentage among all countries surveyed (Eagleman et al., 2014).

When we factor in gender participation percentages and medals won (six out of seven by women), it becomes apparent that Czech online media coverage mirrored equitable success. The largest percentages of articles written, with the exception of the male dominated, culturally primary sport of ice hockey $(n=216,25.1 \%)$, were from the sports of biathlon $(n=107,12.4 \%)$, skiing $(n=136$, $15.8 \%)$, snowboarding $(n=99,11.5 \%)$, and speed skating $(n=89,10.4 \%)$, where Czech medals were won. In fact, three of these four sports also had significantly higher coverage of women than men, sending a strong message that success is more important than gender when examining multi-sport mega events, such as the Olympic Games. These results mirror the findings of others who found that equitable coverage can be explained by nationalist bias, providing significant visibility for female athletic success (Billings \& Angelini, 2007; Delorme, 2014; Eagleman et al., 2014). Media coverage of Czech athletes, similar to that of other nations during the Olympics (Billings et al., 2013; Min \& Zhen, 2010), is used to reinforce national identity. Our results show that when measured in terms of participation and national identity, masculine hegemony largely disappears creating apparent windows of equity.

Ice hockey represents an interesting case in this analysis. As previously stated, $26.6 \%$ of the Czech team was composed of the men's ice hockey team. These 25 men represent the only team sport, and collectively could only win one medal. Proportionality, though clearly driven by market forces, is apparent here as $25.1 \%$ of the articles written covered ice hockey. This finding is in contrast to those of Delorme (2014), who stated that individual Olympic athletes who succeed will typically generate more media coverage than team success. The Czech ice hockey team entered the 2018 Winter Olympics considered a favorite for the gold medal, but lost the bronze medal game to finish fourth. Ice hockey is a primary sport in the country and success in this sport is very closely tied to national identity (Numerato, 2010). Our findings parallel those of Ličen and Billings (2013b), who found increased coverage of expected medal winners in the similarly small, new nation-state of Slovenia. All ice hockey articles written about women $(n=9)$ or covering both $(n=4)$ men and women, concerned success of the two teams which made it to the final, or the unified North/South Korea women's team. This observation reinforces the notion that women may appropriately compete in individual sports, but men still rule the team sports.
Article length was observed to be insignificant between men and women's online media coverage. Thus, our findings confirm those of past studies (Burch et al., 2012; Eagleman et al., 2014; Hardin et al., 2002; Kian et al., 2009), supporting the claim that the internet affords the media to be more equitable in their coverage and consequently present a more accurate depiction of multi-sport mega events. As Burch et al. (2012) stated this is a positive step for the coverage of women. In the context of Czech online media coverage, the findings are remarkably similar to those found by Sekot (2006), 14 years prior, in the context of the Summer Olympic Games. The distribution of media coverage was within $4 \%$ each for men, women and both; but the total coverage allotted was greatly increased via internet coverage. Sekot was examining three print media sources and had a total of 817 articles (number of days was equal, though the Summer Olympics has significantly more events). Our examination only covered two internet sources, resulting in 860 articles, or a $157.9 \%$ increase in total coverage.

Like Burch et al. (2012), our study covers the Winter Olympic Games, which is composed of only one team event, ice hockey. Thus we would add to Coche and Tuggle's (2016) list of socially acceptable sports for women the winter sports of biathlon, cross-country skiing, figure skating, skiing, snowboarding and speed skating. At the same time, we contend that not only is the online media coverage of ice hockey representative of hegemonic masculinity, but also the individual winter sports of bobsleigh and luge, nordic combined and ski jumping.

Similar to the sport gender media studies conducted in Slovenia and Poland (Jakubowska \& Ličen, 2019; Ličen \& Billings, 2013a, 2013b), and in contrast to the Czech Republic's historic resistance to feminist ideology (OatesIndruchová, 2016), the communist era promotion of gender equality and women's empowerment is only upheld as a means of supporting national identity. While coverage of Czech women was significantly bolstered by their out-performance of Czech men, coverage of foreign athletes reflected hegemonic masculinity in granting foreign men $57.2 \%$ of coverage, while only allocating $29.4 \%$ to women. Windows of equity are provided in order to support national identity in coverage of a multi-sport mega event. As Delorme (2014) has stated, national coverage of such events tends to "overrepresent and glorify their athletes" (p. 122). Similar to other studies, proportional gender coverage in sport media around the Olympic Games, provides macro narratives about national values and ideals (Milford, 2012).

The quantitative methodology chosen for this article is only one way of examining equity. While we contend that quantitative differences in coverage between gender, when relative participation is taken into account, does provide evidence of hegemonic masculinity, further qualitative research could be used to further develop these claims. Even if Czech female Olympians are afforded relatively equitable amount of coverage, if they are not framed through their athletic accomplishment, but by how they "do gender" then notions of hegemonic masculinity are reinforced. 
Future research could qualitatively examine media framing as has been conducted on similar data sets by other authors (George et al., 2001; Kian \& Clavio, 2011; Kian et al., 2009; Sekot, 2006; Vincent, 2004).

\section{Conclusions}

Overall, our results, consistent with previous studies, showed more articles written about male athletes, than female. In all sports where Czechs won medals, media coverage exceeded participation percentages. Given that six of the seven medals won by Czechs were won by women, we should not be surprised to have found high correlations between medal winning and media coverage among Czech women. Consequently, our results show that success brought Czech women increased visibility, but inequitable coverage relative to participation, and not relative to their actual success (which would have equaled $85.7 \%$ of coverage).

The question remains, what opens these windows of the apparent equity in media coverage the Czech context? The Czech Republic has traditionally been resistant to feminist ideology. This notion has not meant that hegemonic masculinity was not evident in the culture, but is actually preserved in sport media coverage. However, it appears that when the sport event is important to national identity, such as the Olympic Games, then reporting on the collective success of the national identity supersedes gender identity. Additionally, our research affirms that the move to online media coverage, as others have noted, provides space for more equitable coverage; both in terms of number of articles and length of articles. Finally, we propose that the specific context of winter sports, with the exception of the sport of figure skating, asexualizes athletes. While team sports remain primarily the bastion of men, the only team sport represented in the Winter Olympic Games is ice hockey.

For future studies, the authors believe qualitative analysis, examining gender framing through text and photographs, is needed of Olympic winter sports online media, in order to examine the presence of gendered appropriation of winter sports.

\section{Conflict of interest}

The authors report no conflict of interest.

\section{References}

Adams, N., Schmitke, A., \& Franklin, A. (2005). Tomboys, dykes, and girly girls: Interrogating the subjectivities of adolescent female athletes. Women's Studies Quarterly, 33(1/2), 17-34. https://www.jstor.org/stable/40005499

Billings, A. C., \& Angelini, J. R. (2007). Packaging the games for viewer consumption: Gender, ethnicity, and nationality in NBC's coverage of the 2004 Summer Olympics. Communication Quarterly, 55(1), 95-111. https://doi. org/10.1080/01463370600998731

Billings, A. C., Brown, C. L., Crout, J. H., III, McKenna, K. E., Rice, B. A., Timanus, M. E., \& Ziegler, J. (2008). The games through the NBC lens: Gender, ethnic, and national equity in the 2006 Torino Winter Olympics. Journal of Broadcasting \& Electronic Media, 52(2), 215-230. https://doi.org/10.1080/08838150801992003

Billings, A. C., Brown, N. A., Brown, K. A., Guoqing, Leeman, M. A., Ličen, S., Novak, D. R., \& Rowe, D. (2013). From pride to smugness and the nationalism between: Olympic media consumption effects on nationalism across the globe.
Mass Communication and Society, 16(6), 910-932. https://doi.org/10.1080/15205 436.2013.822519

Brown, K. A., Ličen, S., Billings, A. C., \& Devlin, M. B. (2017). Envisioning Slovenia telecast from Brazil: Relationships between national identity and Slovenian viewership of the 2016 Rio Summer Olympic Games. International Journal of Sport Communication, 10(4), 487-507. https://doi.org/10.1123/ijsc.2017-0062

Burch, L. M., Eagleman, A. N., \& Pedersen, P. M. (2012). New media coverage of gender in the 2010 Winter Olympics: An examination of online media content. International Journal of Sport Management, 13(2), 143-159.

Čáslavová, E., Janák, V., Berka, P., Görnerová, E., \& Balaštíková, K. (2007). Společenská reflexe sportu a jeho prezentace $v$ masmédiích [Social reflection of sport and its presentation in mass media]. In V. Hošek \& P. Tilinger (Eds.), Psychosociální funkce pohybových aktivit jako součást kvality života dospělých (pp. 71-85). Charles University.

Cho, Y. (2009). Unfolding sporting nationalism in South Korean media representations of the 1968, 1984 and 2000 Olympics. Media, Culture \& Society, 31(3), 347-364. https://doi.org/10.1177/0163443709102

Coche, R., \& Tuggle, C. A. (2016). The women's Olympics? A gender analysis of NBC's coverage of the 2012 London Summer Games. Electronic News, 10(2), 121-138. https://doi.org/10.1177/1931243116647770

Connell, R. W. (1990). An iron man: The body and some contradictions of hegemonic masculinity. In M. Messner \& D. Sabo (Eds.), Sport, men, and the gender order (pp. 83-95). Human Kinetics.

Connell, R. W. (2005). Masculinities (2nd ed.). University of California Press.

Cooky, C., Messner, M. A., \& Musto, M. (2015). "It's dude time!" A quarter century of excluding women's sports in televised news and highlight shows. Communication \& Sport, 3(3), 261-287. https://doi.org/10.1177/2167479515588761

Davis, K. K., \& Tuggle, C. A. (2012). A gender analysis of NBC's coverage of the 2008 Summer Olympics. Electronic News, 6(2), 51-66. https://doi. org/10.1177/1931243112452261

Delorme, N. (2014). Were women really underrepresented in media coverage of summer Olympic games (1984-2008)? An invitation to open a methodological discussion regarding sex equity in sports media. Mass Communication and Society, 17(1), 121-147. https://doi.org/10.1080/15205436.2013.816740

Delorme, N., \& Pressland, A. (2016). The visibility of female athletes: A comparison of the Sochi 2014 Winter Olympic Games coverage in French, British, and Spanish newspapers. Sociology of Sport Journal, 33(4), 317-333. https:// doi.org/10.1123/ssi.2016-0017

Eagleman, A., Burch, L. M., \& Vooris, R. (2014). A unified version of London 2012: New-media coverage of gender, nationality, and sport for Olympics consumers in six countries. Journal of Sport Management, 28(4), 457-470. https://doi. org/10.1123/ism.2013-0151

Fink, J. S. (2015). Female athletes, women's sport, and the sport media commercial complex: Have we really "come a long way, baby"? Sport Management Review, 18(3), 331-342. https://doi.org/10.1016/i.smr.2014.05.001

George, C., Hartley, A., \& Paris, J. (2001). The representation of female athletes in textual and visual media. Corporate Communications: An International Journal, 6(2), 94-101. https://doi.org/10.1108/13563280110391007

Gramsci, A. (1971). Selections from the Prison Notebooks, edited and translated by $Q$. Hoare and $G$. Nowell Smith. Lawrence \& Wishar.

Greer, J. D., \& Jones, A. H. (2013). Beyond figure skating and hockey: How U.S. audiences gender type Winter Olympic sports. International Journal of Sport \& Society, 3(4), 129-140.

Hardin, M., Chance, J., Dodd, J. E., \& Hardin, B. (2002). Olympic photo coverage fair to female athletes. Newspaper Research Journal, 23(2-3), 64-78. https:// doi.org/10.1177/073953290202300206

Jakubowska, H., \& Ličen, S. (2019). The role of newspapers in the formation of gendered national identity: Polish coverage of women's and men's basketball championships. International Review for the Sociology of Sport, 54(3), 302324. https://doi.org/10.1177/1012690217719566

Kian, E. M., \& Clavio, G. (2011). A comparison of online media and traditional newspaper coverage of the men's and women's US Open tennis tournaments. Journal of Sports Media, 6(1), 55-84. https://doi.org/10.1353/ism.2011.0004

Kian, E. M., Mondello, M., \& Vincent, J. (2009). ESPN - The women's sports network? A content analysis of Internet coverage of March Madness. Journal of Broadcasting \& Electronic Media, 53(3), 477-495. https://doi. org/10.1080/08838150903102519

Kidd, B. (2013). Sports and masculinity. Sport in Society, 16(4), 553-564. https:// doi.org/10.1080/17430437.2013.785757

Ličen, S., \& Billings, A. C. (2013a). Affirming nationality in transnational circumstances: Slovenian coverage of continental franchise sports competitions. International Review for the Sociology of Sport, 48(6), 751-767. https://doi. org/10.1177/1012690212446821

Ličen, S., \& Billings, A. C. (2013b). Cheering for 'our' champs by watching 'sexy' female throwers: Representation of nationality and gender in Slovenian 2008 Summer Olympic television coverage. European Journal of Communication, 28(4), 379-396. https://doi.org/10.1177/0267323113484438

Maguire, J., \& Poulton, E. K. (1999). European identity politics in EURO 96: Invented traditions and national habitus codes. International Review for the Sociology of Sport, 34(1), 17-29. https://doi.org/10.1177/101269099034001002

Malec, M. A. (1994). Gender (in)equity in the NCAA News? Journal of Sport and Social Issues, 18(4), 376-379. https://doi.org/10.1177/019372394018004006

McCombs, M. (2005). A look at agenda-setting: Past, present and future. Journalism Studies, 6(4), 543-557. https://doi.org/10.1080/14616700500250438 
Milford, M. (2012). The Olympics, Jesse Owens, Burke, and the implications of media framing in symbolic boasting. Mass Communication and Society, 15(4), 485-505. https://doi.org/10.1080/15205436.2012.665119

Min, W., \& Zhen, X. (2010). Mirroring the Olympic games - The Beijing 2008 Olympic Games in the American media. International Journal of the History of Sport, 27(9-10), 1794-1808. https://doi.org/10.1080/09523367.2010.481128

Numerato, D. (2010). Between small everyday practices and glorious symbolic acts: Sport-based resistance against the communist regime in Czechoslovakia. Sport in Society, 13(1), 107-120. https://doi.org/10.1080/17430430903377920

Oates-Indruchová, L. (2016). Unraveling a tradition, or spinning a myth? Gender critique in Czech society and culture. Slavic Review, 75(4), 919-943. https://doi. org/10.5612/slavicreview.75.4.0919

Pokorná, J. (2016). Poznámky k současnému výzkumu obsahu a sledovanosti sportu žen v médiích [Women's sport in media: Present content and audience research highlights]. Sociální Studia, 8(1), 121-138. https://journals.muni.cz/ socialni studia/article/view/5884

Sage, G. H. (1998). Power and ideology in American sport: A critical perspective (2nd ed.). Human Kinetics.

Sekot, A. (2006). Ženy a sport [Women and sports]. Universitas, 2016(3), 3-11. https://iournals.muni.cz/universitas/article/view/2294

Šiklová, J. (1997). Feminism and the roots of apathy in the Czech Republic. Socia Research, 64(2), 258-280. https://www.jstor.org/stable/40971185
Slepičková, I. (2010). Czech Republic: Czech women in the sports media. In T. Bruce, J. Hovden, \& P. Markula (Eds.), Sportswomen at the Olympics (pp. 153165). Sense Publishers. https://doi.org/10.1163/9789460911071 013

Stríteský, V. (2015). Selected perspectives on attitudes of the Czech population towards sport. Studia Sportiva, 9(1), 73-82. https://doi.org/10.5817/StS2015-1-9 True, J. (1999). Expanding markets and marketing gender: The integration of the postsocialist Czech Republic. Review of International Political Economy, 6(3), 360-389. https://doi.org/10.1080/096922999347227

True, J. (2003). Gender, globalization, and postsocialism: The Czech Republic after communism. Columbia University Press.

Věšínová-Kalivodová, E. (2005). Czech society in-between the waves. European Journal of Women's Studies, 12(4), 421-435. https://doi. org/10.1177/1350506805057099

Vincent, J. (2004). Game, sex, and match: The construction of gender in British newspaper coverage of the 2000 Wimbledon Championships. Sociology of Sport Journal, 21(4), 435-456. https://doi.org/10.1123/ss.21.4.435

Vincent, J., Imwold, C., Masemann, V., \& Johnson, J. T. (2002). A comparison of selected 'serious' and 'popular' British, Canadian, and United States newspaper coverage of female and male athletes competing in the Centennial Olympic Games: Did female athletes receive equitable coverage in the 'games of the women'? International Review for the Sociology of Sport, 37(3-4), 319-335. https://doi.org/10.1177/101269020203700312 